\title{
Survival and Growth of Transplanted Orchid Seedlings Enhanced by DCPTA
}

\author{
James H. Keithly, Daniel P. Jones, and Henry Yokoyama \\ U.S. Department of Agriculture, Agricultural Research Service, Fruit \\ and Vegetable Chemistiy Laboratory, 263 South Chester Avenue, \\ Pasadena, CA 91106
}

\begin{abstract}
Additional index words. DCPTA, Brassolaeliocattleya, Dendrobium, Epidendrum radicans, Laeliocattleya, Phalaenopsis
\end{abstract}

\begin{abstract}
The growth-enhancing property of DCPTA was tested on transplanted seedlings of Brassolaeliocattleya $\times$ Hort. (Blc. Bryce Canyon $\times$ LC. Pirate King), Dendrobium $\times$ Blume. Hickham Deb, Epidendrum radicans Pav. ex Lindl., Lueliocattleya $\times$ Rolfe Prism Palette 'The Clown', and Phalaenopsis $\times$ Blume. [Pink Zebra $\times(J u t t a$ Brungor $\times$ Music)]. After 3 to 6 months of greenhouse growth, plants treated with $30 \mu$ DCPTA produced a 2- to 3-fold increase in root growth compared to the controls. Shoot growth, root : shoot ratio, and the survival of DCPTA-treated plants were increased significantly when compared with controls. Chemical name used: 2-(3,4-dichlorophenoxy)triethylamine (DCPTA).
\end{abstract}

Worldwide commercial orchid production has advanced rapidly due to improvements in clonal propagation methods (Churchill et al., 1973; Tanaka and Sakanishi, 1977), hybridization programs (Griesbach, 1985), and air-freight delivery systems. Orchid culture is very time-consuming in that 2 to 5 years are required to produce mature, flowering plants from seed or clonal propagations. Or-

\footnotetext{
Received for publication 7 Feb. 1991. Mention of a product or company name does not imply endorsement by the U.S. Dept. of Agriculture to the exclusion of others that may be suitable. The cost of publishing this paper was defrayed in part by the payment of page charges. Under postal regulations, this paper therefore must be hereby marked advertisement solely to indicate this fact.
}

chid culture requires the routine transfer of seedlings from an aseptic agar culture to greenhouse pot culture. Seedling losses after transplanting often reduce production efficiency and can delay the commercial development of new orchid hybrids. In this study, the effects of DCPTA were examined on the survival and growth of transplanted Epidendrum, Dendrobium, Brassolaeliocattleya, Laeliocattleya, and Phalaenopsis seedlings.

Seedlings of Epidendrum radicans, Dendrobium $\times$ Hickham Deb, and clonal propagules of Laeliocattleya $\times$ Prism Palette 'The Clown' were purchased as 14- to 18-monthold plants grown on aseptic agar media in sealed flasks. Plants of Phalaenopsis $\times[$ Pink Zebra $\times$ (Jutta Brungor $\times$ Music) $]$ and Brassolaeliocattleya $\times(\mathrm{Blc}$. Bryce Canyon $\times$ Lc.
Pirate King) were obtained as 3-month-old seedlings grown in community pots (20 to 25 plants per pot). Plants were removed from the flasks or community pots. For each genus, seedlings of a uniform size were divided by random selection into 60 plants/DCPTA treatment. Orchid seedlings were totally immersed for $2 \mathrm{~h}$ in solutions of 3,30 , or 300 $\mu \mathrm{M}$ DCPTA $(1,10$, and 100 ppm DCPTA, respectively) that contained $0.1 \%$ Tween 80 (v/v). DCPTA had been synthesized and purified according to Poling et al. (1977) and Echols et al. (1981), respectively. Control plants were soaked for $2 \mathrm{~h}$ in $0.1 \%$ Tween $80(\mathrm{v} / \mathrm{v})$. After treatment, seedlings were divided into three replicates of 20 plants each. Each group of 20 seedlings was planted in a $15 \times 38$-cm plastic tray filled with 2 seedling-grade fir bark :1 coarse perlite :1 New Zealand sphagnum moss (by volume). Trays were arranged as a randomized complete block. All genera were grown using the same environmental conditions (Gordon, 1988). Plants were grown in a greenhouse under $40 \%$ Saran shadecloth and received a photosynthetic photon flux (PPF) of 600 to 800 $\mu \mathrm{mol} \cdot \mathrm{m}^{-2} \cdot \mathrm{s}^{-1}$ photosynthetically active radiation (PAR). Photoperiod was adjusted to $12 \mathrm{~h}$ using metal halide lamps (PPF at plant height, $\left.150 \mu \mathrm{mol} \cdot \mathrm{m}^{-2} \cdot \mathrm{s}^{-1} \mathrm{PAR}\right)$. Greenhouse temperature control was maintained at a $28 \pm 4 \mathrm{C}$ day $/ 20 \pm 2 \mathrm{C}$ night. Plants were fertilized every 10 days with $0.5 \mathrm{~g} 30 \mathrm{~N}-$ 4.5P-8.2K/liter that contained chelated $\mathrm{Fe}$ and micronutrients. For each genus, the percentage of seedling survival in each treatment was determined after 3 to 6 months of plant growth. At this time, 20 randomly selected plants from each treatment were divided into shoot and root samples. Leaf areas were determined using a Delta-T video leaf area meter (Decagon Devices, Pullman, Wash.). Dry weights of shoot and root samples were determined after they were dried to constant weight at $70 \mathrm{C}$. All seedling sur- 
Table 1. Effect of DCPTA on the survival and growth of orchid seedlings.

\begin{tabular}{|c|c|c|c|c|c|c|}
\hline $\begin{array}{l}\text { DCPTA } \\
(\mu \mathrm{M})\end{array}$ & DAT $^{\mathbf{z}}$ & $\begin{array}{l}\text { Shoot dry wt } \\
\text { (mg) }\end{array}$ & $\begin{array}{l}\text { Root dry wt } \\
\text { (mg) }\end{array}$ & $\begin{array}{c}\text { Leaf area } \\
\left(\mathrm{cm}^{2}\right)\end{array}$ & $\begin{array}{c}\text { Survival } \\
(\%)\end{array}$ & $\begin{array}{c}\text { Root : } \\
\text { shoot ratioy }\end{array}$ \\
\hline \multicolumn{7}{|c|}{ Epidendrum radicans } \\
\hline 0 & 97 & 73 & 23 & 12.7 & 65.0 & 0.31 \\
\hline 3 & & 113 & 42 & 21.0 & 90.0 & 0.37 \\
\hline 30 & & 166 & 59 & 27.2 & 95.0 & 0.35 \\
\hline 300 & & 119 & 50 & 21.9 & 65.0 & 0.42 \\
\hline Significance $^{x}$ & & $Q^{* *}$ & $Q^{* *}$ & $Q^{* *}$ & $Q^{* *}$ & $\mathrm{~L}^{*}$ \\
\hline \multicolumn{7}{|c|}{ Dendrobium X Hickham Deb } \\
\hline 0 & 126 & 152 & 32 & 20.6 & 78.5 & 0.21 \\
\hline 3 & & 168 & 34 & 20.9 & 80.0 & 0.20 \\
\hline 30 & & 213 & 89 & 24.7 & 85.5 & 0.42 \\
\hline 300 & & 144 & 20 & 20.1 & 75.5 & 0.14 \\
\hline Significance & & $\mathrm{Q}^{*}$ & $\mathrm{Q}^{*}$ & $\mathrm{Q}^{*}$ & $Q^{*}$ & $Q^{*}$ \\
\hline \multicolumn{7}{|c|}{ Lacliocattleya X Prism Palette 'The Clown' } \\
\hline 0 & 93 & 15 & 16 & 4.6 & 80.0 & 1.07 \\
\hline 3 & & 25 & 29 & 7.7 & 88.5 & 1.13 \\
\hline 30 & & 41 & 53 & 12.4 & 91.5 & 1.27 \\
\hline 300 & & 34 & 40 & 9.9 & 72.8 & 1.18 \\
\hline Significance & & $Q^{* *}$ & $Q^{* *}$ & $Q^{* *}$ & $\mathrm{Q}^{*}$ & $\mathrm{~L}^{*} \mathrm{Q}^{*}$ \\
\hline \multicolumn{7}{|c|}{ Brassolacliocattleya X (Blc. Bryce Canyon $\times$ Lc. Pirate King) } \\
\hline 0 & 172 & 325 & 217 & 24.7 & 60.0 & 0.67 \\
\hline 3 & & 413 & 265 & 37.9 & 67.3 & 0.64 \\
\hline 30 & & 525 & 485 & 42.3 & 80.0 & 0.92 \\
\hline 300 & & 366 & 224 & 25.3 & 61.3 & 0.61 \\
\hline Significance & & $Q^{*}$ & $\mathrm{Q}^{*}$ & $Q^{*}$ & $Q^{* *}$ & $Q^{*}$ \\
\hline \multicolumn{7}{|c|}{ Phalaenopsis X [Pink Zebra $\times$ (Jutta Brungor $\times$ Music)] } \\
\hline 0 & 128 & 163 & 169 & 14.1 & 72.3 & 1.04 \\
\hline 3 & & 201 & 222 & 20.0 & 70.0 & 1.10 \\
\hline 30 & & 426 & 483 & 35.7 & 83.5 & 1.13 \\
\hline 300 & & 172 & 162 & 13.7 & 68.7 & 0.94 \\
\hline Significance & & $Q^{* *}$ & $Q^{* *}$ & $Q^{* *}$ & $Q^{*}$ & $\mathrm{Q}^{*}$ \\
\hline
\end{tabular}

Days after DCPTA treatment.

${ }^{y}$ Calculated from dry weight values.

'Significance: linear (L) and quadratic (Q), $P=0.05\left({ }^{*}\right)$ or $0.01\left({ }^{* *}\right)$.

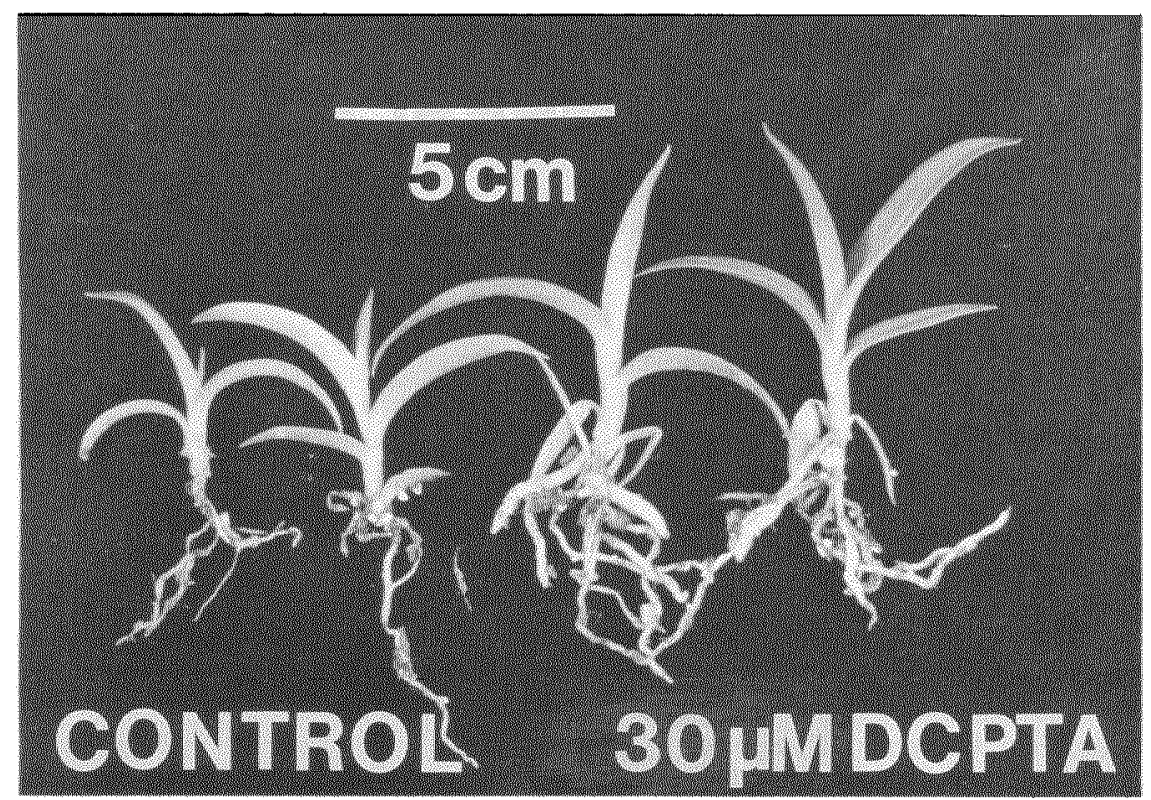

Fig. 1. Typical effect of DCPTA on the seedling growth of Epidendrum radicans. Plants were photographed 97 days after DCPTA treatment.

vival and growth data were subjected to analysis of variance (ANOVA) with linear and quadratic regression analyses. Percentile means were transformed to arcsin values before ANOVA (Zar, 1974). For each genus, DCPTA tests were performed twice. Over time, three independent plant growth experiments were conducted.

Application of DCPTA as a soak treat- ment to transplanted orchid seedlings significantly improved seedling survival and plant growth when compared with controls (Table 1). The dose response characteristics of DCPTA treatment showed significant quadratic responses in the five orchid genera tested. Promotive effects of DCPTA on shoot and root growth were observed at 3 and 30 $\mu \mathrm{M}$, and growth inhibition was observed with
$300 \mu \mathrm{M}$. Typical promotive effects of $30 \mu \mathrm{M}$ DCPTA on seedling growth are shown in Fig. 1. Leaf area development of all plants paralleled shoot development. Linear correlation coefficients of shoot dry weight and leaf area ranged from $r=0.82$ for Dendrobium seedlings to $r=0.91$ for Laeliocattleya seedlings. Root development of plants treated with $30 \mu \mathrm{M}$ DCPTA showed a 2- to 3 -fold increase over the root growth of controls in the five test genera. The acceleration of root growth by DCPTA significantly increased the root: shoot ratio of plants treated with $30 \mu \mathrm{M}$ DCPTA compared with controls. Seedling survival after DCPTA treatment was increased significantly in all genera (Table 1). Significant quadratic responses indicated promotive and inhibitory effects in the 30- and 300- $\mu \mathrm{M}$ DCPTA treatments, respectively.

Primary root elongation and the rate of seedling root development are often used as measures of seedling vigor (Steiner et al., 1989). In this study, DCPTA treatment significantly increased seedling vigor in all genera. These results are consistent with previous studies that showed DCPTA significantly increased the root : shoot ratio of cotton (Gossypium hirsutum L.) (Gausman et al., 1988) and primary root development (Keithly et al., 1991) of seedling plants.

Orchid seedling losses following the transfer of plants from aseptic growth media to pot culture are common, and seedling mortality may exceed $50 \%$ during the first 6 months of greenhouse growth (D. P. J., unpublished results). Our study showed that DCPTA enhanced seedling survival after the transplanting of five commercially important orchid genera. It is important to note that DCPTA enhanced the survival of plants that were transferred from agar cultures to greenhouse pot culture (Epidendrum, Dendrobium, and Laeliocattleya) and of seedlings that were preconditioned to greenhouse pot culture (Brassolaeliocattleya and Phalaenopsis). In a previous study (Keithly and Yokoyama, 1990), DCPTA application to Phalaenopsis seedlings significantly increased the vegetative growth rate and reduced the time to flowering. In this study, $30 \mu \mathrm{M}$ DCPTA significantly enhanced seedling vigor and seedling survival after transplanting. These results suggest that DCPTA may be used to improve seedling productivity and increase the efficiency of orchid production.

\section{Literature Cited}

Churchill, M. E., E.A. Ball, and J. Arditti. 1973. Tissue culture of orchids. I. Method for leaf tips. New Phytol. 72161-166.

Echols, L. C., V.P. Maier, S.M. Poling, and P.R. Sterling. 1981. New bioregulators of gibberellin biosynthesis in Gibberella fijikuroi. Phytochemistry 20:433-437.

Gausman, H.W., H. Yokoyama, J.E. Quisenberry, J.H. Keithly, and J.D. Burd. 1988. Effects of diethylaminoethyl-3,4-dichlorophenylether [DCPTA] on cotton (Gossypium hirsutum L.) root/shoot ratio. Bul. Plant Growth Regulat. Soc. Amer. 16:6-7.

Gordon, B. 1988. Phalaenopsis culture: A world- 
wide survey. Laid-back Publications, Rialto, Calif. p. 12-13.

Griesbach, R.J. 1985. Phalaenopsis orchids as potential pot plants. HortScience 20:624.

Keithly, J.H. and H. Yokoyama. 1990. Regulation of plant productivity I: Improved seedling vigor and floral performance of Phalaenopsis by 2-(3,4-dichlorophenoxy)triethylamine [DCPTA]. Plant Growth Regulat. 9:19-26.
Keithly, J. H., H. Yokoyama, and H.W. Gausman. 1991. Regulation of crop growth and yield by tertiary amine bioregulators, p. 223-246. In: H.W. Gausman (ed.). Plant biochemical regulators. Marcel-Dekker, New York.

Poling, S. M., W.J. Hsu, and H. Yokoyama. 1977. Structure activity relationships of chemical inducers of carotenoid biosynthesis. Photochemistry 14:1933-1938.
Steiner, J.J., D.F. Grabe, and M. Tulo. 1989. Single and multiple vigor tests for predicting seedling emergence of wheat. Crop Sci. 29:782786 .

Tanaka, M. and Y. Sakanishi. 1977. Clonal propagation of phalaenopsis by means of leaf tissue culture. Amer. Orchid Soc. Bul. 46:733-737.

Zar, J.H. 1974. Biostatistical analysis. PrenticeHall, Englewood Cliffs, N.J. 